beginning to feel dissatisfied with the role of science and its present applications to human welfare, and that a material change, if not a complete break, will have to be made with the present economic system before science can be fully utilized. Concern at the insecurity of their own position in the immediate future is leading scientific workers to the view that a new type of scientific organization, based.on the experience of the trade unions in the defence of the economic and cultural interests of large masses of the population, is becoming necessary.

\section{The Earthquake in Turkey}

As the railway between Sivas and the ruins of Erzinjan has now been repaired, it is possible to add a few more details concerning the Erzinjan earthquake of December 27, 1939 (see NATURE of Jan. 6, p. 13). From Ankara to Sivas and Tokat the damage has been done chiefly to the old and badly constructed buildings made from inferior material, whilst the better ferro-concrete public buildings of recent construction have escaped with cracks and minor damage; but from Tokat and Sivas to Erzinjan there has been practically complete destruction of old and new. The only 'oasis' of lesser damage thus far recorded has been at Kemah near Erzinjan, where some buildings still stand, though 548 buildings were wrecked and nearly 150 casualties caused. It appears probable that Kemah was built on more solid rock than the other towns in the area of approximately 15,000 square miles affected.

In the mountainous district between Amasya and Tokat there are ground fissures 12 yards wide, out of which are said to issue smoke and sulphur fumes and also jets of boiling water. There is as yet no direct news of some five hundred villages to the east of Erzinjan, although efforts are being made to reach them through a countryside covered to a depth of $12 \mathrm{ft}$. in snow. At Niksar, a rock pinnacle fell on the town, doing much damage, and there were few survivors in this place or in fourteen of the neighbouring villages, whilst on the Black Sea coast the towns of Kerasun and Ordu are reported to have suffered the greatest damage.

At Kew Observatory the first waves to arrive did so at 0 h. $3 \mathrm{~m}$. 26s. G.M.T. and the maxima exceeded the limits of registration, the ground movement being greater than one millimeter in amplitude. Several severe after-shocks have occurred as well as hundreds of smaller ones. On January 1 there were seven severe after-shocks at Erzinjan, and a violent shock at 7 a.m. local time at Bergama in the west of Turkey. On January 2 at Yozgad there was a strong shock and 190 houses collapsed, though no casualties are reported. The after-shocks appear now to be decreasing in strength and number. Although the after-shock of January 1 was at Bergama, it is yet uncertain whether the floods in the Brusa and Smyrna districts of Turkey and in the Bilecik Valley (River Sakaria) had anything to do with changes in topography attendant on the earthquakes, nor whether the Kemal Pasha Dams and numerous river bridges were destroyed by the shocks or by the floodwaters, but if the meteorological conditions in the area did not cause the floods, they certainly enhanced them considerably.

\section{Other Recent Earthquakes}

ON December 21, San José (Costa Rica) suffered the most severe earthquake it has known since 1923. Buildings were cracked, including the cathedral, though no casualties are reported. The shock was recorded at Manila, at De Bilt (Holland), where the $P$ wave arrived at $2 \mathrm{lh} .7 \mathrm{~m}$. 10s. G.M.T., and at Kew, where the first of three shocks in rapid succession arrived at $21 \mathrm{~h} .6 \mathrm{~m}$. 51s. G.M.T., the maximum ground amplitude at Kew being $0.42 \mathrm{~mm}$. On December 22, considerable damage is reported to have been caused by earthquake shocks in Costa Rica, though no loss of life or other casualties are reported. These shocks were possibly after-shocks of the earthquake which rocked San José on December 21.

On December 22 also severe earthquake shocks were experienced in the South Sea islands of Molucca. On December 23 and 24 earthquakes and landslides, which were probably caused by the earthquakes. occurred in Java in the East Indies. In addition to the Anatolian earthquake of December 27, further shocks were registered at Kew Observatory on December 25 (2), December 28 and December 29. Further news concerning all these shocks is awaited from the areas concerned and from other seismological observatories. On January 2, early in the day, an earthquake shock was perceptible on the Ionian Island of Zante (Greece), though no damage or loss of life has been reported.

\section{Potatoes in War-time}

Potatoes are one of the most valuable sources of human and animal food in war-time, and it is of the greatest national importance that both the acreage devoted to this crop shall be increased and that the maximum yields shall be obtained. Questions of quality, colour and shape must now take second place and yield be the all-important aim of the grower. The National Institute of Agricultural Botany, Cambridge, has just issued a war-time edition of its Farmer's Leaflet No. 3, in which useful information to this end is supplied. Emphasis is laid on the necessity for using healthy seed, as otherwise attention to cultivation, manuring, etc., is of little value. A number of varieties are recommended for both early and main crops; but it is pointed out that to lift potatoes in an unripe condition is an unwarranted waste of tonnage in a time of emergency. As regards choice of varieties, most of those commonly grown are still recommended, but King Edward should be replaced by a heavier cropping kind such as Arran Banner, Arran Consul, Kerr's Pink, Majestic or Redskin.

The use of unsaleable potatoes for animal feeding is the subject of "Growmore" Leaflet No. 10, issued by the Ministry of Agriculture. All potatoes, whether to be used raw or cooked, should be washed before feeding, or digestive trouble may result. Raw potatoes 
can be used safely in moderation for cattle, dairy cows and sheep; but they are not suitable for young stock, horses or pigs. Cooked potatoes, however, can be successfully fed to pigs of all ages, and a table of suitable quantities is provided. Potato and potato and green fodder silage are other useful ways of utilizing waste tubers, particularly if some of them are slightly diseased, and simple methods for preserving them in this way are described. Nutritious food of a feeding value equivalent to about a quarter of its weight of barley meal, and suitable for sheep, cattle and pigs, can thus be produced.

\section{Johann Friedrich Blumenbach (1752-1840)}

JohanN Friedrich Blumenbach, a pioneer in anthropology and eraniology, was born on May 11, 1752, at Gotha. He studied medicine at Jena under Soemmering and qualified in 1776 at Göttingen, where he was appointed extraordinary professor of the practice of medicine in the following year and full professor in 1778. In his thesis entitled "De generis humani varietate nativa" (1776), which according to Garrison is the starting point of modern ethnology, he based his classification of mankind upon the shape of the skull and the facial configuration as well as on the colour of the skin. As the result of his eraniological investigations, he divided the human race into five great families : the Caucasian or white race, the Mongolian or yellow, the Malayan or brown, the Negro or black, and the American or red.

Blumenbach was a voluminous writer. His principal work, which was published in 1790-1820, was entitled "Decades 1-6 collectiones suae craniorum diversarum gentium illustratæ". He was also the author of "Handbuch der Naturgeschichte" (177980), "Ueber der Bildungstrieb und das Zeugungsgeschäft" (1781), "Institutiones physiologicæ" (1787), "Beiträge zur Naturgeschichte" (1790-1811), and "Handbuch der vergleichenden Anatomie" (1805). He was also the editor of "Medicinische Bibliothek" from 1785 until 1795, and contributed many articles to periodical literature. He was a fellow of the Royal Society, member of the Royal Academy of Seiences of Paris, and the recipient of many other honours at home and abroad. He died on January 18, 1840.

\section{Neanderthal Man in Central Asia}

A PRELIMINARY account of the discovery of skeletal remains of Neanderthal man in Central Asia is given by Dr. Aleš Hrdlička through the Smithsonian Institution of Washington. The remains-the skull of a child, with the lower jaw and all the teeth, and some of the bones of the skeleton in a fragmentary state-were found by Dr. A. Nokladnikov in a cave of the Gissar Mountains of Siberia. The discovery is of special importance, as not only is this the first example of Neanderthal man to be recorded from Central Asia, but it is also the farthest extension of the type eastward hitherto known. With the exception of the finds in Palestine, all previous specimens have been found in Europe. Dr. Hrdlička, who has had an opportunity of examining the material while on a visit to Siberia recently, regards it as one of the most important discoveries in anthropology of the last two decades, and further as lending support to his view that there is an overlap in skull pattern between Sinanthropus and Neanderthal man.

In an account of the find which Dr. Hrdlička received at first hand from those who were responsible for the discovery, it was stated that the cave deposits contained many splintered bones of deer, leopards, wild horses, goats, boars, marmots and birds. Many of these showed evidence of having been used in the manufacture of stone implements. Most of these implements were made of local limestone, but the finest were of jasper. Good material for implementmaking, however, was scarce. Typical Mousterian scrapers and small pointed implements, chipped on one side, were associated with the animal bones, and both were in relation to fire-places. The human skeletal remains were imbedded in a sterile underlying stratum. An interesting feature of their disposal was that they were encircled by five pairs of goat horns, of which three were still united.

\section{Psychology of the Initiate}

An interesting sidelight is thrown on certain changes in mentality taking place after initiation by an examination of two series of drawings made by an Australian aboriginal boy, which have been recorded and reproduced by C. P. Mountford, acting ethnologist of the South Australian Museum (Records S. Austral. Mus., 6, 2 ; 1939). The subject was one of two interpreters accompanying an anthropological expedition of the University of Adelaide to the Warburton Ranges of Western Australia in 1935. At the time of his engagement it was understood that he was a full initiate ; but when an investigation of aboriginal art was being made, it was noted that when drawings of a secret character were being made by tribesmen, they were carefully concealed on his approach. His own drawings in the first series invariably represented objects of, or known to, European civilization.

This fact, coupled with his failure as an interpreter, led to inquiry, when it was found that initiation of the man had not been completed. 'Though circumcized, he had not been subincized, and consequently in all matters affecting tribal ritual he was virtually ostracized, while his behaviour consorted with that of younger members of the tribe. Full initiation, which was then carried out, induced a remarkable change in his outlook, behaviour, and what from one point of view was of greater moment, in the attitude of other members of the group. The youth assumed the attitude and behaviour of a senior of the tribe; he was no longer prevented from seeing cerernonial drawings and taking part in ritualistic discussions, while, it is interesting to note, his own drawings now depicted the ceremonial designs associated with, or recording tribal traditions. The author's comment is significant. He points out how any interference with tribal ritual by outside influence may prove an effectual bar to association with tribal society, while still not securing an admission to any real participation in white civilization. The lesson is instructive. 